\title{
Identification of European species of Maja (Decapoda: Brachyura: Majidae): RFLP analyses of COI mtDNA and morphological considerations
}

\author{
GUILLERMO GUERAO ${ }^{1}$, KARL B. ANDREE ${ }^{1}$, CARLO FROGLIA ${ }^{2}$, \\ CARLES G. SIMEÓ ${ }^{1}$ and GUIOMAR ROTLLANT ${ }^{1}$ \\ ${ }^{1}$ IRTA, Unitat Operativa de Cultius Aquàtics, Ctra. Poble Nou, Km 5.5, 43540 Sant Carles de la Ràpita, Tarragona, Spain. \\ E-mail: guillermo.guerao@irta.cat \\ ${ }^{2}$ Istituto di Scienze Marine (CNR), Largo Fiera della Pesca, 60125 Ancona, Italia.
}

\begin{abstract}
SUMMARY: Four species of crabs of the genus Maja have been described along the European coast: M. brachydactyla, M. squinado, M. goltziana and $M$. crispata. The commercially important species $M$. brachydactyla and $M$. squinado achieve the largest body sizes and are the most similar in morphology, and are therefore easily confused. The four species of Maja were identified using a novel morphometric index and a polymerase chain reaction followed by restriction fragment length polymorphism analysis (RFLP). The relationship between carapace length and the distance between the tips of antorbital spines was used to distinguish adults of $M$. brachydactyla and $M$. squinado. PCR-RFLP analysis of a partial sequence of the mitochondrial cytochrome oxidase type I (COI) revealed that the four species of the genus Maja can be unambiguously discriminated using the combination of restriction endonucleases enzymes $\mathrm{HpyCH} 4 \mathrm{~V}$ and Ase I. The molecular identification may be particularly useful in larvae, juvenile and young crabs, when the morphological differences found in adults are not applicable.
\end{abstract}

Keywords: Maja, M. squinado, M. brachydactyla, molecular identification, morfometry, COI, RFLP.

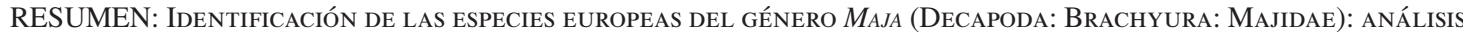
DE PCR-RFLP DE UNA REGIÓN DEL mtADN COI Y CONSIDERACIONES MORFOLóGICAS. - Cuatro especies del género Maja han sido descritas en las costas europeas: M. brachydactyla, M. squinado, M. goltziana y M. crispata. Las especies M. brachydactyla y M. squinado, que tienen importancia comercial, alcanzan los tamaños más grandes y son morfológicamente muy similares, siendo muy fácil confundirlas. La identificación de las cuatro especies se ha realizado utilizando un nuevo índice morfométrico y un análisis de polimorfismos de fragmentos de restricción (RFLP). La relación entre la longitud del cefalotórax y la distancia entre los extremos distales de las espinas antorbitales se ha utilizado para la diferenciación de los adultos de M. brachydactyla y $M$. squinado. El análisis PCR-RFLP de una secuencia parcial de la citocromo oxidasa tipo I mitocondrial (COI) indica que las cuatro especies del género Maja pueden ser discriminadas usando una combinación de las endonucleasas HpyCH4V y Ase I. La identificación molecular puede ser particularmente útil en las larvas, juveniles y cangrejos jóvenes, cuando las diferencias morfológicas encontradas en los adultos no son aplicables.

Palabras clave: Maja, M. squinado, M. brachydactyla, identificación molecular, morfometría, COI, RFLP.

\section{INTRODUCTION}

Four species of spider crabs of the genus Maja Lamarck, 1801 (Majoidea, Majidae) have been reported along the European coast: $M$. brachydactyla Balss, 1922; M. crispata Risso, 1827; M. goltziana
D'Oliveira, 1888; and M. squinado (Herbst, 1788) (Neumann, 1998; Sotelo et al., 2008, 2009). Maja brachydactyla and M. squinado are of high commercial value due to their larger size (Števčić, 1974; Le Duff, 1990). While M. goltziana adults are easily identified by the presence of a strong dorso-distal 
spine on the merus of the pereiopods (Zariquiey-Álvarez, 1968; Neumann, 1998), discrimination among the other three species is more difficult. M. crispata, the smallest species, shows considerable ontogenetic variation and has characters that overlap with $M$. brachydactyla and M. squinado (Neumann, 1996). Balss (1922) erected M. squinado var. brachydactyla on three specimens from Canary Islands with short walking legs. For some years this taxon has been considered a synonym of $M$. squinado (ZariquieyÁlvarez, 1968; Neumann, 1996; Ng et al., 2008). However, Neumann (1998) pointed out that Atlantic populations of " $M$. squinado" are separable from those of the Mediterranean based on morphological and biometrical characters, which justifies the recognition of two different species. However, species identification using the key morphological characters for adult Majidae of Neumann (1998) may be difficult for non-specialists to apply. Results of recent genetic analyses support the recognition of $M$. brachydactyla and M. squinado as different species (Sotelo et al., 2008, 2009). M. brachydactyla has been reported in the eastern Atlantic, while M. squinado is restricted to the Mediterranean Sea (Neumann, 1998; d'Udekem d'Acoz, 1999; Sotelo et al., 2008, 2009).

The larval stages of the Atlanto-Mediterranean species of Maja are morphologically very similar (Clark, 1986; Paula, 1988; Rodríguez, 2002; Guerao et al., 2008), with the zoea stages being virtually indistinguishable. The morphology of juveniles is also very similar; at least for M. brachydactyla (Guerao and Rotllant, 2009) and M. squinado (Guerao and Rotllant unpublished data). The possibility of correctly identifying all development stages (larvae, juveniles, adults) of a species is a prerequisite for all studies on population dynamics aimed at developing proper management of fisheries resources and their commercialization.

Among the different polymerase chain reaction (PCR) methods of genotype analysis, restriction fragment length polymorphism (RFLP) of PCR-amplified mitochondrial DNA (mtDNA) fragments has been recently used to identify different crustacean species (e.g. Bossier et al., 2004; Khamnamtong et al., 2005; Van Stappen et al., 2007). Sequence variation at the COI mtDNA barcode region has been shown to be effective for discriminating crustacean species (Costa et al., 2007).

The aim of this paper is to provide a useful molecular technique for identifying all the European species of the genus Maja at all stages of development, and also to provide new morphological and morphometric characters that allow easy differentiation between $M$. brachydactyla and M. squinado specimens.

\section{MATERIALS AND METHODS}

A total of 149 adult specimens of the four species of genus Maja collected between 2007 and 2010 in the Atlantic and Mediterranean Sea were used in morphological and/or molecular analyses (Table 1). One pereiopod of each individual was preserved in 94-100\% ethanol for posterior DNA extraction. For the morphological study, additional individuals (carapaces) conserved in the laboratory were also measured $(\mathrm{n}=13 M$. brachydactyla $; \mathrm{n}=8 M$. squinado $)$. The following measurements were taken: carapace length (CL) as the distance between the rostral margin (without rostral spines) and the posterior margin of the carapace (without intestinal spines); and antorbital spine length (ANSL), measured as the distance between the tips of the antorbital spines (the spine at the posterolateral corner of the supraorbital eave; see Figs. 1 and 2). The relationship between CL and ANSL was studied using least squares analysis of linear regression $(\log$ ANSL $=\log a+b \log C L)$. Regression was performed using a SigmaStat 3 (Systat Software Inc., USA) software package. The significance of the correlation was tested with a t-test $\left(\mathrm{H}_{0}: \rho=0, \mathrm{H}_{1}: \rho \neq 0\right)$, and the regression equations were compared with the F-test $\left(\mathrm{H}_{0}: \mathrm{a}_{1}=\mathrm{a}_{2}, \mathrm{~b}_{1}=\mathrm{b}_{2}\right)$ (Cuadras, 1991).

TABLE 1. - Sampling locations and number of individuals for molecular and morphological studies of Maja. Abbreviations: GB, GenBank accession number; MO, morphological studies; n, number of crabs; RF, RFLP studies; T, total studied individuals.

\begin{tabular}{|c|c|c|c|c|c|c|c|}
\hline Species & Collection sites & Coordinates & Year & $\underset{\mathrm{n}}{\mathrm{MO}}$ & $\underset{\mathrm{n}}{\mathrm{RF}}$ & $\begin{array}{l}\mathrm{T} \\
\mathrm{n}\end{array}$ & $\begin{array}{c}\text { COI sequences } \\
\text { GB }\end{array}$ \\
\hline Maja squinado & $\begin{array}{l}\text { W Mediterranean (Catalonia, Spain) } \\
\text { Central Mediterranean (Adriatic Sea, Italy) } \\
\text { W Mediterranean (Corsica, France) } \\
\text { Previous studies }\end{array}$ & $\begin{array}{l}43.9^{\circ} \mathrm{N} 13.8^{\circ} \mathrm{E} \\
42.0^{\circ} \mathrm{N} 9.0^{\circ} \mathrm{E} \\
41.1^{\circ} \mathrm{N} 1.2^{\circ} \mathrm{E} \\
-\end{array}$ & $\begin{array}{l}2007-09 \\
2009 \\
2010\end{array}$ & $\begin{array}{l}22 \\
17 \\
5 \\
-\end{array}$ & $\begin{array}{l}7 \\
20 \\
8 \\
-\end{array}$ & $\begin{array}{l}25 \\
20 \\
8 \\
-\end{array}$ & $\begin{array}{l}\text { GU902709 } \\
\text { HM572324, HM572326 } \\
\quad- \\
\text { EU000832-35, GQ153551 }\end{array}$ \\
\hline Maja brachydactyla & $\begin{array}{l}\text { E Atlantic (Galicia, Spain) } \\
\text { E Atlantic (Grand Casablanca, Morocco) } \\
\text { SW Mediterranean (Ceuta, Spain, Africa) } \\
\text { Previous studies }\end{array}$ & $\begin{array}{l}42.2^{\circ} \mathrm{N} 8.7^{\circ} \mathrm{W} \\
33.6^{\circ} \mathrm{N} 7.6^{\circ} \mathrm{W} \\
35.9^{\circ} \mathrm{N} 5.3^{\circ} \mathrm{W}\end{array}$ & $\begin{array}{l}2007-08 \\
2009 \\
2009\end{array}$ & $\begin{array}{c}30 \\
10 \\
9\end{array}$ & $\begin{array}{c}10 \\
20 \\
6\end{array}$ & $\begin{array}{c}36 \\
20 \\
9\end{array}$ & $\begin{array}{l}- \\
- \\
\text { GU902706-08, GU902711-13 } \\
\text { EU000811-31, GQ153550 }\end{array}$ \\
\hline Maja crispata & $\begin{array}{l}\text { W Mediterranean (Catalonia, Spain) } \\
\text { Central Mediterraean (Adriatic Sea, Italy) } \\
\text { Previous studies }\end{array}$ & $\begin{array}{l}41.1^{\circ} \mathrm{N} 1.2^{\circ} \mathrm{E} \\
43.6^{\circ} \mathrm{N} 13.5^{\circ} \mathrm{E}\end{array}$ & $\begin{array}{c}2008-09 \\
2009\end{array}$ & $\begin{array}{c}4 \\
16\end{array}$ & $\begin{array}{c}5 \\
20\end{array}$ & $\begin{array}{c}5 \\
20\end{array}$ & $\begin{array}{l}\text { GU902710 } \\
\quad- \\
\text { EU000836-49, GQ153554 }\end{array}$ \\
\hline Maja goltziana & $\begin{array}{l}\text { E Mediterranean (Antalya, Turkey) } \\
\text { Central Mediterranean (Malta Archipelago) } \\
\text { Previous studies }\end{array}$ & $\begin{array}{l}36.8^{\circ} \mathrm{N} 30.7^{\circ} \mathrm{E} \\
35.7^{\circ} \mathrm{N} 14.2^{\circ} \mathrm{E}\end{array}$ & $\begin{array}{l}2009 \\
2009\end{array}$ & 4 & $\begin{array}{l}5 \\
1\end{array}$ & $\begin{array}{l}5 \\
1\end{array}$ & $\begin{array}{l}\text { GU939594 } \\
\text { HM572325 } \\
\text { GQ153555 }\end{array}$ \\
\hline
\end{tabular}


Total genomic DNA extraction was performed with muscle tissues using the QIAamp DNA Mini Kit (QIAGEN Inc). The concentration of DNA was estimated by spectrophotometry, using a GeneQuant pro. The $710 \mathrm{bp}$ region of the mitochondrial cytochrome oxidase subunit I gene was amplified using universal primers LCO1490 (5'-GGT CAA CAA ATC ATA AAG ATA TTG G -3') and HCO2198 (5'-TAA ACT TCA GGG TGA CCA AAA AAA TCA-3') described by Folmer et al. (1994). Amplification was carried out with 80-100 ng of genomic DNA in a reaction containing $1 \mathrm{U}$ of Taq polymerase (Invitrogen), 1X buffer (Invitrogen), $2 \mu \mathrm{M}$ of each primer and $800 \mu \mathrm{M}$ dNTPs. The PCR thermal profile used was $95^{\circ} \mathrm{C}$ for $5 \mathrm{~min}$ for the initial denaturation, and 39 cycles at $94^{\circ} \mathrm{C}(20 \mathrm{~s})$, $42^{\circ} \mathrm{C}(20 \mathrm{~s}), 72^{\circ} \mathrm{C}(30 \mathrm{~s})$ with a final extension at $70^{\circ} \mathrm{C}$ for $7 \mathrm{~min}$. In order to estimate the size of restriction fragments precisely, the mitochondrial COI gene was sequenced from 2-10 individuals for each restriction pattern obtained (Table 1). Sequencing reactions were performed with the ABI PRISM ${ }^{\circledR}$ BigDye ${ }^{\mathrm{TM}}$ Terminator Ready Reaction Cycle Sequencing kit, v3.1 (Applied Biosystems); the products were analyzed in an automated sequencer ABI PRISM 310 (Applied Biosystems). Sequencing reactions were carried out by an external laboratory (Sistemas Genómicos ${ }^{\circledR}$, Valencia, Spain). In addition, sequences of all four species of Maja from GenBank were analyzed (Table 1). To identify conserved nucleotide residues useful for an RFLP analysis, sequence alignment was performed using the BioEdit software (Hall, 1999). The amplification products were then incubated with two restriction enzymes, HpyCH4V (recognition site: 5'- TG'CA -3'/3'- AC'GT $-5^{\prime}$ ) and Ase I (recognition site: 5'- AT'TAAT -3'/3'TAAT'TA -5') (New England Biolabs). Digestion was performed in a $20 \mu \mathrm{L}$ mixture that contained $10 \mu \mathrm{L}$ of PCR product, $25 \mathrm{U}$ of $\mathrm{HpyCH} 4 \mathrm{~V}, 50 \mathrm{U}$ Ase I and NEB digestion Buffer 2. Restriction enzyme digestions were incubated for $3.5 \mathrm{~h}$ at $37^{\circ} \mathrm{C}$. Restriction fragments were electrophoretically separated on $1.5 \%$ agarose in 1X TBE buffer, stained with ethidium bromide and visualized under UV light. The number of individuals analyzed is shown in Table 1 .

\section{RESULTS}

The CL/ANSL ratio is different in $M$. squinado in relation to other European species of the genus Maja. Thus, the CL/ANSL ratio is $<3$ in M. brachydactyla (CL/ ANSL=2.52 \pm 0.1$), M$. crispata $(\mathrm{CL} / \mathrm{ANSL}=2.01 \pm 0.1)$ and $M$. goltziana (L/ANSL $=2.5 \pm 0.06$ ), but $>3$ in M. squinado (CL/ANSL=3.24 \pm 0.12 ). The correlation between ANSL and CL is highly significant in $M$. brachydactyla $(\mathrm{t}=53.9 ; \mathrm{P}<0.001)$, M. squinado $(\mathrm{t}=55.8$; $\mathrm{P}<0.001)$ and M. crispata $(\mathrm{t}=23.1 ; \mathrm{P}<0.001)$ (Fig. 1). The equations of the regression of ANSL on CL for $M$. brachydactyla and $M$. squinado are significantly different between the two species $(\mathrm{F}=682.2 ; \mathrm{P}<0.005$; Fig. 1). In addition, the regression of ANSL on CL in

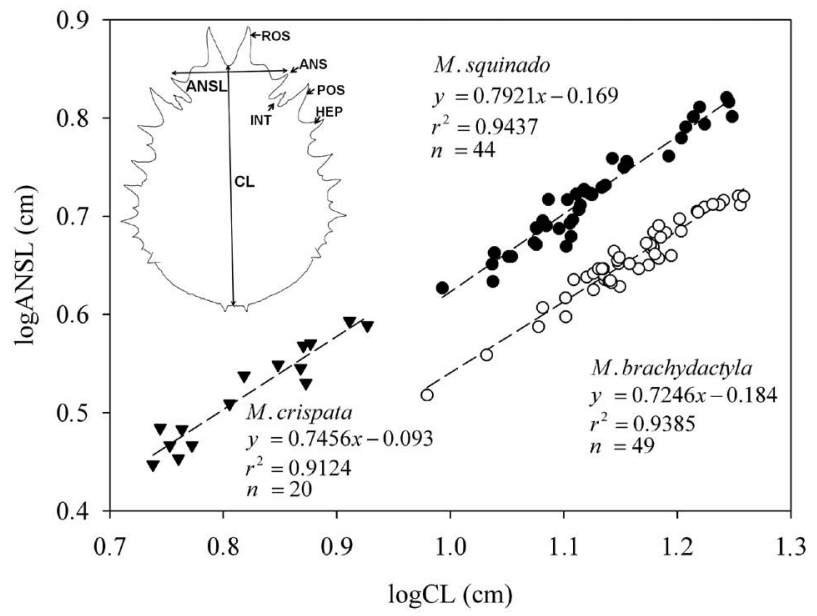

FIG. 1. - Relationship between carapace length (CL) and the distance between the tip of the antorbital spines (ANSL) in Maja brachydactyla, $M$. squinado and $M$. crispata. ANS, antorbital spine; INT, intercalated spine; HEP, hepatic spine; POS, postorbital spine; ROS, rostral spine.

M. crispata is significantly different from $M$. squinado $(\mathrm{F}=6.10 ; \mathrm{P}<0.005 ;$ Fig. 1$)$ and $M$. brachydactyla $(\mathrm{F}=72.01 ; \mathrm{P}<0.005)$. The small number of $M$. goltziana available made a regression analysis impossible. In addition to the CL/ANSL ratio, the shape and orientation of the antorbital spines have been shown to be a useful tools for easy identification of adult individuals of $M$. brachydactyla and $M$. squinado. Thus, while the antorbital spine in M. brachydactyla is curved and directed upward vertically, it is slightly curved, thinner, more pointed and slightly oblique from vertical in $M$. squinado (Fig. 2).

\section{PCR-RFLP analyses}

The size of the COI mtDNA fragment amplified in the four species was $710 \mathrm{bp}$. Restriction fragment length polymorphism analysis revealed that the four species can be unambiguously discriminated using the restriction enzymes $\mathrm{HpyCH} 4 \mathrm{~V}$ and Ase I (Fig. 3). As expected, digestion with both enzymes produced a specific pattern for M. crispata $(9,99,227$ and 375 bp), M. squinado (333 and 377 bp), M. goltziana (15, 122, 198 and $375 \mathrm{bp}$ ), and $M$. brachydactyla, which exhibited an alternative specific restriction pattern (the

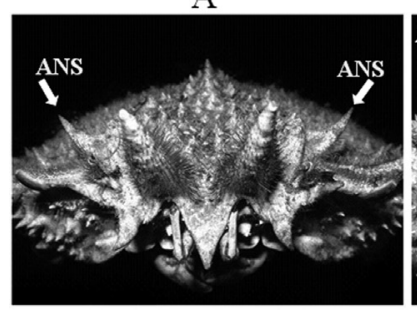

FIG. 2. - Shape and orientation of the antorbital spines (frontal view). Maja squinado (A); M. brachydactyla (B). Antorbital spines (ANS). 


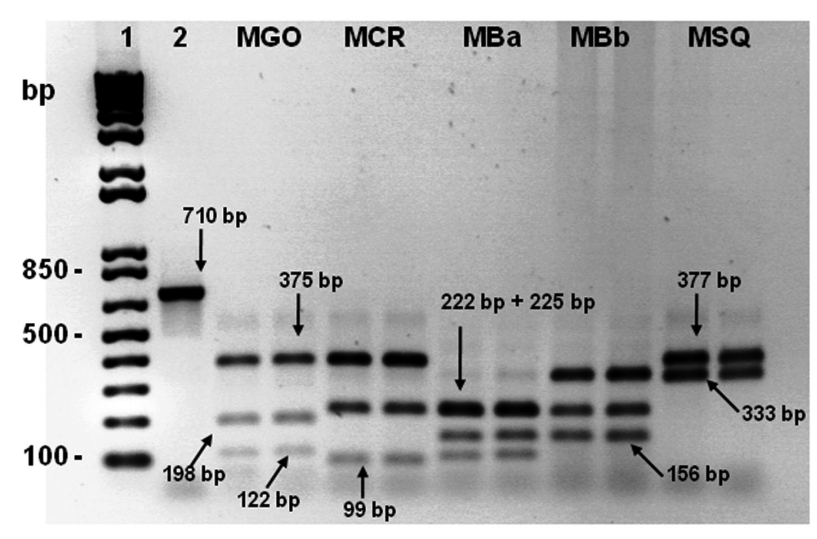

FIG. 3. - RFLP analysis of the COI mtDNA segments after digestion with $H p y C H 4 V$ and Ase I. Molecular weight standard (1); undigested fragment (2); Maja goltziana (MGO); M. crispata (MCR); $M$. brachydactyla, pattern a $(\mathrm{MBa}) ; M$. brachydactyla, pattern $\mathrm{b}$ (MBb); M. squinado (MSQ).

most frequent MBa, 108, 154, 222 and 226 bp versus $\mathrm{MBb}$ 156, 221 and $333 \mathrm{bp}$, the least frequent). These alternative patterns (b) occur due to a point mutation at the enzyme recognition site for Ase I (Fig. 4) observed in $11 \%$ of $M$. brachydactyla individuals from all collection sites (Galicia $(n=1)$, Morocco $(n=2)$ and Ceuta $(n=1)$; see Table 1$)$. In addition, the mutation at the enzyme recognition site related to pattern $b$ can be observed in $14.3 \%$ of $M$. brachydactyla sequences from GenBank. None of the studied individuals of $M$. squinado and $M$. goltziana contained the recognition site for the Ase I enzyme (Fig. 4). It should be noted that $M$. squinado individuals may show one or two enzyme recognition sites for $\mathrm{HpyCH} 4 \mathrm{~V}$; however, as both sites are very close ( 5 bp, see Fig. 4 ) the restriction patterns are indistinguishable.

\section{DISCUSSION}

The morphological differentiation of the European species in the genus Maja is sometime problematic due to a considerable amount of character overlap and ontogenetic variation. Maja brachydactyla and M. squinado reach the largest body sizes (exceeding $20 \mathrm{~cm}$ in carapace length) and they are the most similar species. Neumann (1998) reported that the different morphology of the male first gonopod is particularly useful for identifying the two species. Thus, the proximal margin of the distal region of the gonopod is rounded with gradual transition to the terminal process in M. brachydactyla, while it shows an angled outline and abrupt transition into a terminal process in M. squinado. However, the distinctive characters of the male first gonopod are subject to ontogenetic changes, making the identification of juvenile individuals very difficult or impossible.
117
126
222
233
M. brachydactyla a
TAATIGCTCCGG
M. brachydactyla $\mathrm{b}$
M. crispata
M. squinado
M. squinado
M. goltziana

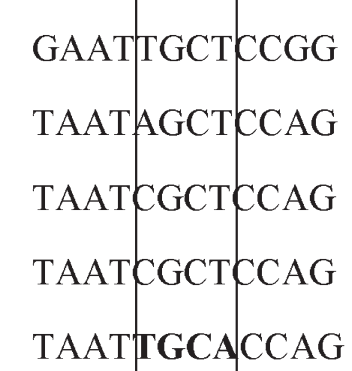
GTATATTAATCACG
GTATGTTAATCACG
GCATATTAATTACA

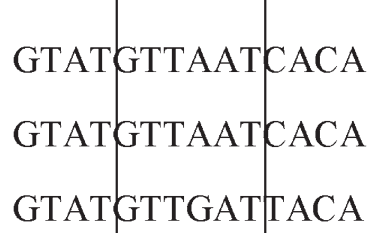

315

338

538

547

M. brachydactyla a

M. brachydactyla $\mathrm{b}$

M. crispata

M. squinado ${ }^{1}$

M. squinado ${ }^{2}$

M. goltziana
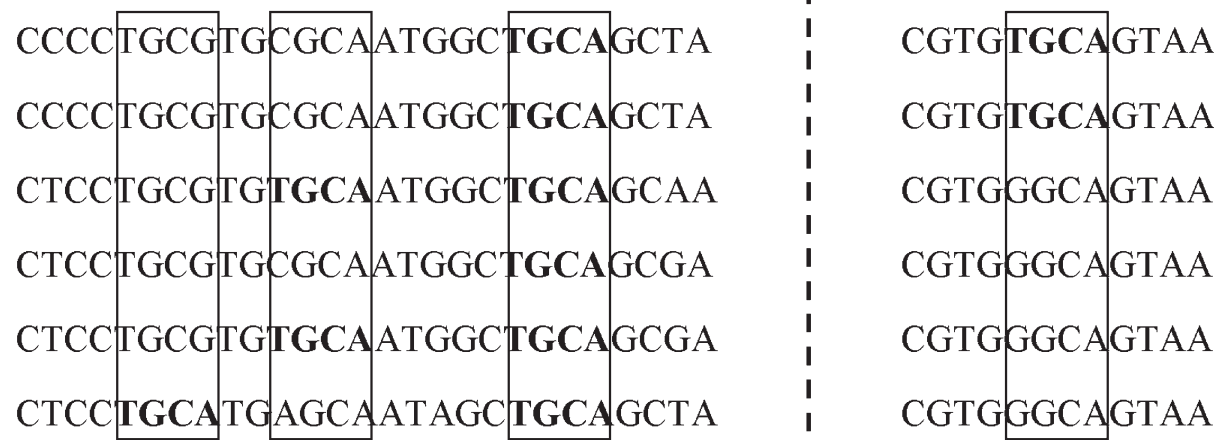

FIG. 4. - Position of HpyCH4V and Ase I restriction sites on the COI segment. M. brachydactyla a, GU902708; M. brachydactyla b, GU902707; M. crispata, GU902710; M. squinado ${ }^{1}$, GU902709; M. squinado², HM572326; M. goltziana, HM572325. 
Moreover, the study of gonopods requires dissection and detailed microscope observations. In the present study, it was demonstrated that a simple relationship between CL and ANSL is a good morphometric index to differentiate adult individuals of both sexes (CL larger than $9.8 \mathrm{~cm}$ ) of $M$. brachydactyla and $M$. squinado (see Figs. 1 and 2). However, early juveniles of the two species do not differ in this character and are nearly indistinguishable (Guerao and Rotllant, 2009, 2010). The great similarity between the juveniles of related brachyuran species has been previously documented; species distinction is very difficult at the early postlarval stages, and phenotypic divergence increases with juvenile ontogeny (Ingle and Rice 1984; Martin et al., 1984; Felder et al., 1985; Neumann 1996). The adult individuals of $M$. crispata are smaller than adults of $M$. brachydactyla and $M$. squinado. This species can only be confused with juveniles of the two larger European species of Maja.

Identification of crustacean species using PCRRFLP analysis has been well documented (Power et al., 1999; Bossier et al., 2004; Khamnamtong et al., 2005; Hisar et al., 2008; Pascoal et al., 2008; Dharani et al., 2009). The PCR-RFLP technique, to be diagnostic, must be applied to DNA regions that are highly conserved within species but sufficiently variable between species. The COI mtDNA region has been shown to be a good marker for crustacean species (Costa et al., 2007). Importantly, mtCOI is sufficiently variable to be useful in identifying and discriminating even the most closely related species (Lefébure et al., 2006; Bucklin et al., 2007, 2009; Darling and Tepolt, 2008). Sotelo et al. (2008) reported that the COI region displays diagnostic differences between species of the genus Maja; divergence between species was much higher than within them. The low level of intraspecific variation observed among the three species indicates that the COI gene fragment amplified utilizing the primers of Folmer et al. (1994) is a suitable marker for identifying Majidae species in the NE Atlantic and Mediterranean Sea. Using a combination of restriction enzymes (HpyCH4V and Ase I) proved useful for discriminating all four Maja European species.

Analysis of $M$. brachydactyla samples, from the eastern Atlantic (Spain, Galicia; and Morocco, Grand Casablanca) to SW Mediterranean (Spain, Ceuta), and $M$. squinado and $M$. crispata samples from the western (Spain, Catalonia) and central (Italy, Adriatic Sea) Mediterranean revealed identical restriction patterns among individuals of the same species. It should be noted that the specimens of Maja originating from Ceuta, on the Mediterranean coast (near the Strait of Gibraltar), have been unambiguously assigned to the species $M$. brachydactyla (Table 1). The presence of strictly eastern Atlantic coastal species in the Alboran Sea has been reported in several instances and related to the inflow of the less dense Atlantic surface water into the Mediterranean Sea through the Strait of Gibraltar (García Raso, 1984; García Muñoz et al., 2008; Lasram et al., 2008).
The molecular identification technique might be especially useful when dealing with larvae or juvenile individuals, which do not have the discriminating morphological characters of adults (Chow et al., 2006; Tang et al., 2009). The PCR-RFLP technique, which allows the four Maja species to be identified at any development stage, would contribute to the understanding of their life histories and hence to the management of their exploitation. It may also have forensic applications when fraud is suspected in the commerce of the two species ( $M$. brachydactyla and $M$. squinado), as they are subject to different capture and marketing regulations.

\section{ACKNOWLEDGEMENTS}

Financial support was provided by the Ministry of Science and Research to GG (post-doctoral fellowship; INIA). Bench fees were funded by the Spanish Ministry of the Environment and Rural and Marine Areas (JACUMAR, REPES project). The authors thank Francisco Javier Martínez Medina from the Environmental Government of Ceuta (Consejería de Medio Ambiente, Ciudad de Ceuta) for collecting and shipping adult specimens from this area.

\section{REFERENCES}

Balss, H. - 1922. Crustacea VII: Decapoda Brachyura (Oxyrhyncha und Brachyrhyncha) und geographische Übersicht über Crustacea Decapoda. In: W. Michaelsen (ed.), Beiträge zur Kenntnis der Meeresfauna Westafrikas, pp. 69-110. Friederichsen and Co., Hamburg.

Bossier, P., W. Xiaomei, F. Catania, S. Dooms, G. Van Stappen, E. Naessens and P. Sorgeloos. - 2004. An RFLP database for authentication of commercial cyst samples of the brine shrimp Artemia spp. (International Study on Artemia LXX). Aquaculture, 231: 93-112.

Bucklin, A., P.H. Wiebe, S.B. Smolenack, N.J. Copley, J.G. Beaudet, K.G. Bonner, J. Färber-Lorda and J.J Pierson. - 2007. DNA barcodes for species identification of euphausiids (Euphausiacea, Crustacea). J. Plank. Res., 29(6): 483-493.

Bucklin, A., R.R Hopcroft, K.N. Kosobokova, L.M. Nigro, B.D. Ortman, R.M. Jennings and C.J. Sweetman. - 2009. DNA barcoding of Artic Ocean holozooplankton for species identification and recognition. Deep-Sea Res. II, 57: 40-48.

Clark, P.F. - 1986. The larval stages of Maja squinado (Herbst, 1788) (Crustacea: Brachyura: Majidae) reared in the laboratory. J. Nat. Hist., 20: 825-836.

Costa, F.O., J.R. deWaard, J. Boutillier, S. Ratnasingham, R.T. Dooh, M. Hajibabaei and P.D.N. Hebert. - 2007. Biological identifications through DNA barcodes: the case of the Crustacea. Can. J. Fish. Aquat. Sci., 64: 272-295.

Chow, S., N. Suzuki, H. Imai and T. Yoshimura. - 2006. Molecular species identification of spiny lobster phyllosoma larvae of the genus Panulirus from the northwestern Pacific. Mar. Biotechnol., 8: 260-267.

Cuadras, C.M. - 1991. Problemas de probabilidades y estadística. Vol. 2: Inferencia estadística. Promociones y Publicaciones Universitarias, S.A. Barcelona.

Darling, J.A. and C.K. Tepolt. - 2008. Highly sensitive detection of invasive shore crab (Carcinus maenas and Carcinus aestuarii) larvae in mixted plankton samples using polymerase chain reaction and restriction fragment length polymorphisms (PCRRFLP). Aquat. Invasions, 3(2): 141-152.

Dharani, G., G.A. Maitrayee, S. Karthikayalu, T.S. Kumar, M. Anbarasu and M. Vijayakumaran. - 2009. Identification of Рапиlirus homarus puerulus larvae by restriction fragment length 
polymorphism of mitochondrial cytochrome oxidase I gene. Pak. J. Biol. Sci., 12(3): 281-285.

Felder, D.L., J.W. Martin and J.W. Goy. - 1985. Patterns in early postlarval develpment of decapods. In: A.M. Wenner (ed.), Larval Growth. Crustacean Issues. F. Schram (series ed.) Vol. 2. pp. 163-225. Rotterdam: Balkema Press.

Folmer, O., M. Black, W. Hoeh, R. Lutz and R. Vrijenhoek. - 1994. DNA primers for amplification of mitochondrial cytochrome c oxidase subunit I from diverse metazoan invertebrates. Mol. Mar. Biol. Biotechnol., 3: 294-299.

García Muñoz, J.E., M.E. Manjón-Cabeza and J.E. García Raso. 2008. Decapod crustacean assemblages from littoral bottoms of the Alborán Sea (Spain, west Mediterranean Sea): spatial and temporal variability. Sci. Mar., 72(3): 437-449.

García Raso, J. E. - 1984. Brachyura of the coast of Southern Spain. Spixiana, 7(2): 105-113.

Guerao, G., E. Pastor, J. Martin, M. Andrés, A. Estévez, A. Grau, J. Duran and G. Rotllant. - 2008. The larval development of Maja squinado and M. brachydactyla (Decapoda, Brachyura, Majidae) described from plankton collected and laboratory-reared material. J. Nat. Hist., 42(33-34): 2257-2276.

Guerao, G. and G. Rotllant. - 2009. Post-larval development and sexual dimorphism of the spider crab Maja brachydactyla (Brachyura, Majidae). Sci. Mar., 73(4): 797-808.

Guerao, G. and G. Rotllant. - 2010. Development and growth of the early juveniles of the spider crab Maja squinado (Brachyura, Majidae) in an individual culture system. Aquaculture, 307: $105-110$.

Hall, T.A. - 1999. BioEdit: a user-friendly biological sequence alignment editor and analysis program for Windows 95/98/NT. Nucleic. Acids. Symp. Ser., 41: 95-98.

Hisar, S.A., E. Aksakal, O. Hisar, T. Yanik and S. Mol. - 2008. Discrimination of penaeid shrimps with PCR-RFLP analysis. $J$. Shellf. Res., 27(4): 917-920.

Ingle, R.W. and A.L. Rice. - 1984. The juvenile stages of eight swimming crab species (Crustacea: Brachyura: Portunidae); a comparative study. Bull. Br. Mus. Nat. Hist. (Zool.), 46: 345-354.

Khamnamtong, B., S. Klinbunga and P. Menasveta. - 2005. Species identification of five penaeid shrimps using PCR-RFLP and SSCP analyses of $16 \mathrm{~S}$ ribosomal DNA. J. Biochem. Mol. Biol., 38(4): 491-499.

Lasram, F.B.R., J.A. Tomasini, M.S. Romdhane, T.D. Chi and D. Mouillot. - 2008. Historical colonization of the Mediterranean Sea by Atlantic fishes: do biological traits matter? Hydrobiologia, 607: 51-62.

Le Duff, A. - 1990. L' araignée. France Eco Pêche, 350:41-45.

Lefébure, T., C.J. Douady, M. Gouy and J. Gibert. - 2006. Relationship between morphological taxonomy and molecular divergence within Crustacea: Proposal of a molecular threshold to help species delimitation. Mol. Phylogenet. Evol., 40: 435-447.

Martin, J.W., D.L. Felder and F.M. Truesdale. - 1984. A comparative study of morphology and ontogeny in juvenile stages of four western Atlantic xanthoid crabs (Crustacea: decapoda:
Brachyura). Phil. Trans. R. Soc. Lond. B, 303: 537-604.

Neumann, V. - 1996. Comparative investigations on the systematics and taxonomy of european Maja species (Decapoda, Brachyura, Majidae). Crustaceana, 69: 821-852.

Neumann, V. - 1998. A review of the Maja squinado (Crustacea: Decapoda: Brachyura) species-complex with a key to the eastern Atlantic and Mediterranean species of the genus. J. Nat. Hist., 32(10-11): 1667-1684.

Ng, P. K. L., D. Guinot and P.J.F. Davie. - 2008. Systema Brachyurorum: Part I. An annotated checklist of extant Brachyuran crabs of the world. Raffles Bull. Zool., Suppl. 17: 1-286.

Pascoal, A., J. Barros-Velázquez, A. Cepeda, J.M. Gallardo and P. Calo-Mata. - 2008. A polymerase chain reaction-restriction fragment length polymorphism method based on the analysis of a 16S rRNA/tRNA ${ }^{\text {Val }}$ mitochondrial region for species identification of commercial penaeid shrimps (Crustacea: Decapoda: Penaeoidea) of food interest. Electrophoresis, 29: 499-509.

Paula, J. - 1988. The larval development of Maja goltziana d'Oliveira 1888 (Crustacea, Decapoda, Majidae) reared in the laboratory. J. Nat. Hist., 22: 1697-1708.

Power, A. M., S. Piyapattanakorn, R.M. O'Riordan, A. Iyengar, A.A. Myers, S.J. Hawkins, J. Delany, D. McGrath and N. Maclean. - 1999. Verification of cyprid size as a tool in the identification of two European species of Chthamalus barnacles using mtDNA-RFLP analysis. Mar. Ecol. Prog. Ser., 191: 251-256.

Rodríguez, A. - 2002. Larval development of Maja crispata Risso 1827 (Crustacea, Decapoda, Majidae) reared in the laboratory. J. Nat. Hist., 36: 1589-1600.

Sotelo, G., P. Morán and D. Posada. - 2008. Genetic identification of the northeastern Atlantic spiny spider crab as Maja brachydactyla Balss, 1922. J. Crustac. Biol., 28(1): 76-81.

Sotelo, G., P. Morán and D. Posada. - 2009. Molecular phylogeny and biogeographic history of the European Maja spider crabs (Decapoda, Majidae). Mol. Phylogenet. Evol., 53: 314-319.

Števčić, Z. - 1974 Problemi privrednog iskoristavanja Brahiurnih rakova sjevernog Jadrana. Acta Adriat., 16(22): 397-400.

Tang, R.W.K., C. Yau and W.C. Ng. - 2010. Identification of stomatopod larvae (Crustacea: Stomatopoda) from Hong Kong waters using DNA barcodes. Mol. Ecol. Resour., 10(3): 439-448

Udekem d'Acoz, C. d'- 1999. Inventaire et distribution des crustacés décapodes de l'Atlantique nord-oriental, de la Méditerranée et des eaux continentales adjacentes au nord de $25^{\circ} \mathrm{N}$ Patrimoines naturels (M.N.H.N./S.P.N.), 40.

Van Stappen, G., H. Yu., X. Wang, S. Hoffman, K. Cooreman, P. Bossier and P. Sorgeloos. - 2007. Occurrence of allochthonous Artemia species in the Bohai Bay area, PR China, as confirmed by RFLP analysis and laboratory culture tests. Fundam. Appl. Limnol., 170: 21-28.

Zariquiey-Âlvarez, R. - 1968. Crustáceos decápodos ibéricos. Inv. Pesq., 32: 1-510.

Scient ed.: E. Macpherson.

Received March 17, 2010. Accepted June 16, 2010.

Published online December 23, 2010. 